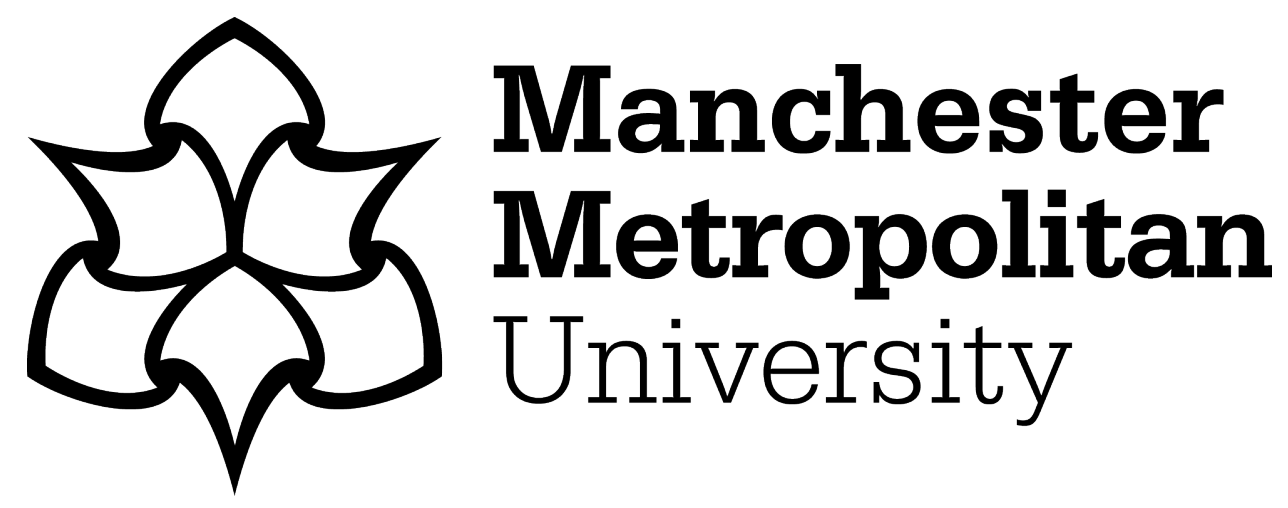

Arun, Shoba, Annim, S and Arun, T (2016) Do All Networks 'Work'? The Mediating Role of Social Networks on Consumption Expenditure in India. Sociology, 50 (3). pp. 522-541. ISSN 0038-0385

Downloaded from: https://e-space.mmu.ac.uk/621314/

Version: Published Version

Publisher: Sage

DOI: https://doi.org/10.1177/0038038515583638

Usage rights: Creative Commons: Attribution 3.0

Please cite the published version 
Do All Networks 'Work'?

\title{
Shoba Arun
}

Manchester Metropolitan University, UK

\section{Samuel Annim \\ University of Cape Coast, Ghana}

\section{Thankom Arun}

University of Central Lancashire, UK

\begin{abstract}
The article sheds light on the mediating role of social networks on consumption behaviour, a significant facet of social mobility and well-being. Based on the Indian Human Development Survey, the article explores to what extent households across India participating in social networks have increased their consumption levels. While participation in formal social networks does result in improved household consumption levels, the type and number of networks are pivotal to this change. Nevertheless, not all networks lead to similar effects, although the number of social networks per se has a positive effect on consumption. Furthermore, the networks based on homogeneous groups, such as women's self-help groups, have a negative or lesser effect on smoothing consumption, while those affiliated with heterogeneous networks have a positive effect on increasing consumption.
\end{abstract}

\section{Keywords}

assets, consumption, India, social capital, social mobility, social networks

\section{Introduction}

Studies of social mobility have increasingly emphasised the importance of social networks as an important tenet of social capital. Most approaches within the social sciences treat social capital either as a form of productive asset or as a form of social relations

\section{Corresponding author:}

Shoba Arun, Department of Sociology, Manchester Metropolitan University, Manchester MI5 6LL, UK.

Email: s.arun@mmu.ac.uk 
(Bourdieu and Wacquant, 1992; Collier, 2002; Marques, 2011; Portes, 1998) exhibiting a degree of the liminality of social and economic processes in social mobility. In this article, we explore the effects of social networks on consumption behaviour in households, and we define networks that relate to participation in collectives that are formal in nature. Here, social networks as a form of social capital are dynamic, defined as both the flow and stock of social relations based on norms and networks which enhance resource flow to households, allowing for changes in the consumption behaviour. The second section of this article identifies aspects of relationships between social capital, networks and household consumption expenditure. The third section discusses the findings from an empirical enquiry into the influence of networks on household consumption expenditure, based on the National Household Panel Survey in India. The final sections present the discussion of results and conclusions.

\section{Social Networks and Consumption Expenditure: Conceptual Framework}

It is widely acknowledged that social capital is seen as a vital resource unequally distributed in society, with varying outcomes for different groups in society. Evidence of social capital at the macro level shows how trust and civic engagement relate to higher levels of growth (Heller, 1996; Krishna and Uphoff, 1999), while at the micro level, individual factors such as incentives to invest in social capital such as education, or networks such as family or group membership, are significant (Costa and Kahn, 2001). This article acknowledges the miscellany of approaches, and identifies the need for a more nuanced understanding of the mediating role of social capital in mobility studies. Given the exhaustive discussion on social capital in the literature, we only refer to the literature on social networks as a form of social capital. Drawing from Portes (1995: 8): 'Networks are important in economic life because they are the sources for the acquisition of scarce means, such as capital and information, and because they simultaneously impose effective constraints on the unrestricted pursuit of personal gain.' As illustrated by Fedderke et al. (1999), forms of social capital (such as networks) display functions of 'transparency' and 'rationalisation' allowing for outcomes such as the flow of information and reduced transaction costs. For Bourdieu and Wacquant (1992: 119), social capital can be defined as: 'the sum of the resources, actual or virtual, that accrue to an individual or group by virtue of possessing a durable network of more or less institutionalised relationships of mutual acquaintance and recognition'. Social networks could be distinguished from other forms of capital through the element of externality generated by the 'social' element, involving interaction, which may have economic effects (Collier, 2002). For example, Putnam (1993) shows that gaining trust through joining social clubs such as amateur choirs generates externalities and reduces transaction costs.

This article draws on social networks as a form of social capital that households belong to, based on a wider conception of 'assets' (referring to capital) that people both possess and use in their daily lives (Bebbington, 1999). This allows us to situate social networks as an 'asset' (Moser and Dani, 2008) and to analyse the nature and pattern of relationships of members of households with key actors such as the state, market and community. This pattern of connections reflects a multitude of factors, some operating at 
the level of the individual, others more at a macro level associated with cultural, economic or political dimensions of society (Gilchrist and Kyprianou, 2011; Wetherell, 2009). This article is more concerned with the micro-level relationship of households within the wider sphere of community and civil society.

It is important to parse out elements of density and closure in social networks, that are akin to social capital, by embedding social relations within and between social groups (Halpern, 2005). The distinction between types, density and strength of networks is relevant here - we refer to two types of capital, that is, bonding networks relate to social networks between homogeneous groups operating with common interests, for example women's groups, and bridging networks that include socially heterogeneous groups allowing for wider networking and exchange of resources among diverse interest groups. Thus, as Fukuyama (1999: 2) states, there is a variation of 'radius of trust' between these two groups. Further strong ties may exist between homogeneous groups, but may reinforce exclusive identities and be inward looking; while bridging social capital may be based on weak ties, yet more outward looking, comprising people of different social cleavages - particularly the much discussed sub-types of bonding and bridging (Gittel and Vidal, 1998; Putnam, 2000). Thus, benefits to members of such groups can vary with different types of social networking, reverberating the classic distinction between 'weak' and 'strong' ties noted by Granovetter (1973). Further, the type of network and strength of ties have an important bearing on information generated and exchanged (Durbin, 2011), while the types and number of networks play an important role in defining the nature of social capital that is generated (Arun et al., 2013). Further, the homogeneity of groups may also limit the nature of information and resource flow as all members have access to the same networks. This article adopts a 'connectionist' view of social capital that integrates both the bridging and bonding elements of social capital, the rationale being that while it is bonding social capital that assists and supports a household, its benefits are limited due to the similar levels of information and resources throughout the network. It is only when bridging capital enters that more resources/information are brought into the network and distributed, leading to greater outcomes in achieving wellbeing. This allows for concerted focus on resource flow through social ties (e.g. Putnam, 2000), and to see if these two types of network vary in their outcomes for household consumption. In the South American context, Godinot et al. (2007) and Perlman (2007) show how social networks serving as social and political assets, engendering both agency and improving capabilities, enable social mobility. Yet the explorations of the link between social networks and consumption, of particular significance to our study, are limited to a few studies that focus on individual consumption and leisure practices and taste (Warde and Tampubolon, 2002). There is some reference by Marques (2011) to how networks affect access to goods and services in São Paulo, where networks may enhance or mitigate the effects of poverty through segregation. Other studies show that the membership of (female) self-help groups has shaped individual consumption practices (Trinies et al., 2011).

This article specifically examines how social relationships embedded through social networks influence the consumption expenditure of households, through improving access to resources, information and opportunities. It is relevant here to draw on the concept of social exchange based on the work of Blau (1967), who emphasises the 
importance of the structure of social position on social life and the formation of different networks. Evidence points to the effects of social isolation through resource monopoly by the rich (e.g. Blokland and Savage, 2008; Caldeira, 2001) or reduced access to information and cultural repertoires by those with lower socio-economic status (Briggs, 2005), accentuated by different social groupings, as in the case of immigrants in Italy (Andreotti, 2006).

In India, social policies play a critical role in the creation of social networks, enabled through the co-influences of state, market and family. In India, the Human Development Index (HDI) shows an increase of 21 per cent between 1999/2000 and 2007/08 in education and health (GOI, 2011), showing increasing levels of welfare and social mobility across India. Further, the average monthly per capita consumption expenditure (in real terms) in India rose consistently in both rural and urban regions between 2004-05 and 2009-10, reflected in a reduction in the incidence of poverty. As Shanker and Gaiha (2011) found, political and social networks are critical for raising awareness of development programmes such as the National Rural Employment Guarantee Scheme (NREGS) in India that increases information, trust, reciprocity and resource flow. For example, Narayan and Pritchett (1999) show how 'trust' as a form of social capital is important within communities. This article considers whether membership of networks in formal organisations produces benefits among different social groups on social, gendered and spatial inequalities. This is important as, often, structural power relations lead to biased working of patronage networks in resource redistribution. This is also an unintended consequence of 'negative' social capital, in the sense that poor households are often disadvantaged in accessing and deciding key issues that affect them locally. They lack favourable 'allies' in the social hierarchy of power structures (Dolfsma and Dannreuther, 2003) and it can be questioned whether social networks as an asset may complement or substitute for other productive assets (Chantarat and Barrett, 2012).

In particular, the role of power structures in mediating with an asset base among different social groups is relevant in the Indian context. For example, marginalised groups either constitutionally recognised as Scheduled Tribes (STs), Scheduled Castes (SCs) or minorities such as Muslims, do possess a weaker asset base which is the source of their higher levels of poverty (Borooah, 2010; Thorat, 2010). Vanneman et al. (2006) show the importance of status groups (defined by caste and religion) on social networks, where Brahmins (upper castes) have the most contacts while STs are less connected, and Muslims have the fewest contacts. In India, the states of Chhattisgarh, Orissa, Bihar, Madhya Pradesh, Jharkhand, Uttar Pradesh, Rajasthan and Assam, comprising the economically poor states belonging to the BIMARU group, record an HDI below the national average (GOI, 2011). The composition of social groupings within such regions is also important in the context of India, as the eight poorest states contain nearly 48 per cent of all SCs, 52 per cent of STs and 44 per cent of all Muslims in the country. Thus, social grouping also influences the levels of economic and social inequality across regions, and observations on social interactions between and within such groups are important for this article. In a similar vein, women may have access to an increased resource base through networks such as self-help groups (SHGs), and this has further implications for household welfare (Doss, 2006) with a direct bearing on women's empowerment (Friedemann-Sánchez, 2006) and bargaining power (Bhattacharyya et al., 2011; Panda and Agarwal, 2005). 
Against this background, this study examines the effect of social networks on consumption expenditure per se, specifically in relation to: (1) density (number of networks that an individual belongs to or number of networks within a society); (2) intensity (degree of connections between and within groups); and (3) pay-off (outcomes associated with groups). However, the potential complexity in measuring the impact of social networks weights the value given to different social networks: the weight of varying degrees of connections between and within groups; and the effect of a number of social networks within a community, participating in a social network and variations in cost and demands of social networks. We distinguish between types of network, with varying opportunities for generating formal versus informal networks. We ask whether the levels and types of social network are significant in improving consumption expenditure, and whether this produces similar effects on gender, regions and other social divisions. This is because the degree of the knowledge gap depends on: (1) whether the number of social networks matters for welfare; and (2) whether participation in any kind of formal network provides a stimulus for policies on social welfare and mobility. Therefore, the main objective is to investigate the effect of the number and type of social networks on household welfare (with consumption expenditure as a proxy) in India.

\section{Methodology and Data}

The 2004-05 Indian Human Development Survey (IHDS) is a nationally representative, multi-topic survey of 41,554 households in 1503 villages and 971 urban neighbourhoods across India, covering topics concerning health, education, employment, economic status, marriage, fertility, gender relations and social capital. It is structured into individual, household and village-level datasets, although the household is the unit of analysis for the current study (based on the nature of our dependent variable: consumption expenditure per capita), and we rely on a sample of 41,237 households for the analysis. This sample constitutes 99 per cent of the sample in the original data set. Although we use the household data, some individual and village-level variables were extracted from the respective datasets. We estimate the usual determinants of poverty model, but with concentration on the effect of: (1) whether a household member belongs to a social network; (2) number of social networks affiliated to a household; and (3) type of social network. The 2005 IHDS village-level survey gathers information on the presence of 13 social networks in a village, including women's groups such as Mahila Mandal, ${ }^{1}$ youth club, sports group, trade union-professional group, self-help groups, credit or savings group, religious or social group, caste association, development group or NGO, agricultural or milk cooperative and political network. ${ }^{2}$ In this article, we choose Mahila Mandal as the reference group on the basis that it is the only one that is restricted to women.

Ordinary least squares (OLS) estimation (first and second stage) is used; however, results based on a logit model (where the dependent variable is whether the household is below the poverty line or not) is provided in Appendix Table 1 for cross-reference. Four variants of OLS regression and an instrumental variable model were estimated. First, we examine the effect of whether being involved in a social network affects poverty, using a dummy response of whether any household member belonged to a social network as the main explanatory variable. Second, we capture a social network as a count variable based 
on the number of social networks that are affiliated to a household. That is, we count the number of social networks affiliated to a household based on social network membership of individuals in the household. Third, we investigate the quadratic of a number of social networks to explore non-linearities between monthly consumption expenditure per capita and number of social networks. Finally, we examine the effect of different types of social network on monthly consumption expenditure per capita.

Other explanatory variables are: rural/urban settlement, household structure and composition (size, dependency ratio, the number of working adults and sex of the head), whether the household belongs to a scheduled tribe or caste, the number of household members with at least higher secondary education, household ownership of land and geographical location dummies. For the sake of comparability, we use the same set of other explanatory variables (that is, with the exception of our main variable of interest - social network) in each of the four models. Also, for ease of interpretation and data smoothing, we take the logarithm of monthly consumption expenditure per capita (proxy for poverty) in estimating all the models. The results were verified based on mundane post-estimation techniques/approaches such as reporting robust coefficients to correct for heteroskedasticity, checking for omitted variables using Ramsey's specification test, dealing with non-normality of residuals and inspecting the presence and effect of multicollinearity. For the sake of brevity, these tests are not reported in the article. However, the current study considers the issue of endogeneity as both theory and empirical work suggest that social network capital and poverty (income/expenditure) are bi-causally related (Chantarat and Barrett, 2012; Narayan and Pritchett, 1999).

As is the case with all other micro-econometric empirical work that uses Instrumental Variable (IV) to address endogeneity, finding an appropriate instrument (defined in the context of strength) is always daunting. Although Narayan and Pritchett (1999) deal with endogeneity in their estimation, we are sceptical about the strength of the instrument used in their article (individual 'trust' in various groups). Our scepticism is informed by the following: first, the relevance of the instrument. In this context, there is the need to examine the strength of an instrument based on the two definitions of weak instruments provided by Stock and Yogo (2005). Their viewpoint suggests that weak instrument(s) examination should be based on, first, bias of the IV estimator relative to the bias of OLS and, second, the value of the alpha level of the Wald test. The latter implies that by engaging in IV, the entire model should be examined. The results from Narayan and Pritchett (1999) show that although the standard error for cluster-level social capital reduces in the case of the IV estimation compared to OLS, some of the other variables in their model show varying signs and higher standard errors. Among the possible reasons for this variation between IV and OLS could be the relevance of the instrument used. Second, since conceptualisation of social capital is primarily dependent on both social network and 'trust' (Paldam, 2000; Vanneman et al., 2006), we remain sceptical of the intuition underlying the use of 'trust' as an instrument for social network. That is, since either social network or 'trust' (or both) can be used as a proxy measure for social capital and the source of endogeneity is a bi-causal relationship between social capital and poverty, then the use of 'trust' as an instrument is difficult to justify.

In this article, we use the number of social networks and other recreational facilities in a village as an instrument for the number of social networks affiliated to a household. 
Table I. Household social network affiliation by key correlates.

\begin{tabular}{|c|c|c|c|}
\hline Correlates & & $\begin{array}{l}\text { Proportion of } \\
\text { household with social } \\
\text { network affiliation }\end{array}$ & Chi-square test \\
\hline \multirow{2}{*}{$\begin{array}{l}\text { Household is below the poverty } \\
\text { line }\end{array}$} & Yes & 17.13 & \multirow[t]{2}{*}{$160.96(0.00)$} \\
\hline & No & 82.87 & \\
\hline \multirow[t]{2}{*}{ Residence of household } & Rural & 76.42 & \multirow[t]{2}{*}{$404.03(0.00)$} \\
\hline & Urban & 23.58 & \\
\hline \multirow{2}{*}{$\begin{array}{l}\text { Household belongs to scheduled } \\
\text { caste/tribe }\end{array}$} & Yes & 29.88 & \multirow[t]{2}{*}{$0.03(0.86)$} \\
\hline & No & 70.12 & \\
\hline \multirow[t]{5}{*}{ Location of household } & North' & 3.73 & \multirow[t]{5}{*}{$2.80(0.00)$} \\
\hline & BIMARU $^{2}$ & 20.53 & \\
\hline & South ${ }^{3}$ & 52.75 & \\
\hline & East $^{4}$ & 22.51 & \\
\hline & Others ${ }^{5}$ & 0.49 & \\
\hline \multirow{2}{*}{$\begin{array}{l}\text { Household owns agricultural } \\
\text { land }\end{array}$} & Yes & 49.22 & \multirow[t]{2}{*}{$356.85(0.00)$} \\
\hline & No & 50.78 & \\
\hline Total & - & $4 I .24(I 7,032)$ & - \\
\hline
\end{tabular}

Notes:

'North states are Jammu \& Kashmir, Himachal Pradesh, Punjab, Uttaranchal and Haryana. 2BIMARU states are Bihar, Madhya Pradesh, Rajasthan and Uttar Pradesh.

${ }^{3}$ South states are Gujarat, Maharathra, Andhra Pradesh, Karnataka, Kerala, Tamil Nadu and Pondicherry. ${ }^{4}$ East states are Sikkim, Arunachal Pradesh, Nagaland, Manipur, Mizoram, Tripura, Meghalaya, Assam, West Bengal Jharkhand, Orissa and Chhatisgarh.

${ }^{5}$ Other states are Delhi, Goa, Daman \& Diu and Dadra+Nagar Haveli.

The justification is that the number of social networks that are affiliated to a household will be dependent on the number of social networks in the village, and the latter can only be related to household poverty through household members who join social networks. From a statistical viewpoint, we test the two conditions of validity based on the Anderson canonical correlation LM statistic and Cragg-Donald Wald F-statistic. The latter tests the null hypothesis that the equation is under-identified (suggesting that the excluded variables are irrelevant, that is uncorrelated with the endogenous regressor). The CraggDonald Wald F-statistic provides several thresholds to facilitate a decision on the extent of the weakness of the instrument used. Stock and Yogo (2005) computed critical values, suggesting that in the case of one instrument, then the decision rule should be based on the value 10. The null hypothesis underlying the 'weak' identification test is that the equation is weakly identified. In addition to the above test, we perform the Durbin-WuHausman test of endogeneity.

\section{Findings and Discussion}

The discussion of results is preceded by a cross-tabulation of the relationship between household affiliation to social networks and some selected correlates of social networks (Table 1) and descriptive statistics (Appendix Table 1). The last row of Table 1 shows 
that in India, two in every five households have at least one member belonging to a social network. The cross-tabulations in Table 1 represent the chi-square test statistic which tests the hypothesis of independence between household social network affiliation and its correlates. With the exception of the cross-tabulation between scheduled caste/tribe and social network, all other associations are statistically significant. The second row of Table 1 shows that of the households that are affiliated to a social network, 80 per cent are above the poverty line.

The classification of geographical areas is informed by both geographical location and poverty, as mentioned above, as the states constituting BIMARU are relatively poorer than the other classifications and the category 'others' has the least proportion of households below the poverty line (less than 1\%) based on the 2005 IHDS data (see Appendix Table 2). In our analysis, we find that regional differences are also marked, as states in the southern regions of the country constitute more than half of the proportion of households with at least one member affiliated to a social network. This is an interesting observation as other studies show such regional differences in the coverage of SHGs throughout the country, with a stronger presence in southern states such as Andhra Pradesh (Raja Reddy and Reddy, 2012). In total there are about 796,000 SHGs, with an estimated membership of 97 million (NABARD, 2012). Thus the inequalities in the number of social networks across regions may also point to inequalities in levels of economic indicators. Further, we find that rural-urban residence is also important as less than a quarter of the households with social network affiliation are resident in urban areas, showing a lower penetration of networks in rural areas where social divisions could be higher.

Table 2 presents the four variants of least squares estimations. Column 2 shows that a household with at least one member affiliated to a social network leads to an increase in monthly consumption per capita of approximately 11 per cent. Also observed in column 3 is an increase of approximately 5 per cent in monthly consumption per capita for an additional household affiliation with a social network. We further explore potential nonlinearities between the number of social networks and monthly consumption per capita in column 4. The negative sign of the square of the number of social networks indicates that the observed increases reach only a certain point before decreasing. The calculated turning point after which the response to increases in the number of social networks leads to a fall in consumption is approximately nine networks. However, we are less optimistic about this finding as the number of respondents beyond this point is only 0.06 per cent of the entire sample (see Wooldridge, 2009 for further discussion).

Column 4 in Table 2 examines the effect of different types of social network on consumption. We observe that except for self-help group membership, household affiliation with all the other networks compared to women-based SHGs (i.e Mahila Mandal) leads to higher consumption per capita. Significant variations are observed with the coefficients of the different types of social network. Compared to Mahila Mandal, households with at least one member affiliated with a development agency or an NGO are likely to increase their consumption by 20 per cent, while households with caste social network associations are able to increase consumption by only 4 per cent.

In line with our hypotheses, we find that factors such as geographical residence, educational status, size of household and the number of infants impacted on consumption 
Table 2. Robust regression results of the effect of social networks on poverty (log of monthly consumption per capita).

\begin{tabular}{|c|c|c|c|c|}
\hline \multirow[t]{2}{*}{ Explanatory variables } & \multicolumn{3}{|c|}{ Least squares estimation } & \multirow{2}{*}{$\begin{array}{l}\text { Type of } \\
\text { network } \\
\text { affiliated to } \\
\text { household }\end{array}$} \\
\hline & $\begin{array}{l}\text { Whether } \\
\text { household is } \\
\text { affiliated to a } \\
\text { social network }\end{array}$ & $\begin{array}{l}\text { Number of } \\
\text { networks } \\
\text { affiliated to } \\
\text { household }\end{array}$ & $\begin{array}{l}\text { Square of } \\
\text { the number } \\
\text { of networks }\end{array}$ & \\
\hline $\begin{array}{l}\text { Dummy for social network }(=1 \\
\text { if a household }\end{array}$ & 0.11 & - & - & - \\
\hline $\begin{array}{l}\text { member belongs to at least one } \\
\text { network) }\end{array}$ & {$[17.94]^{* *}$} & - & - & - \\
\hline \multirow[t]{2}{*}{ Number of social networks } & - & 0.05 & 0.07 & - \\
\hline & - & {$[20.74]^{* *}$} & {$[12.95]^{* *}$} & - \\
\hline \multirow{2}{*}{$\begin{array}{l}\text { Number of social networks } \\
\text { squared }\end{array}$} & - & - & -0.00 & - \\
\hline & - & - & {$[-3.20]^{* *}$} & - \\
\hline \multirow{2}{*}{$\begin{array}{l}\text { Member of youth/sports/ } \\
\text { reading' }\end{array}$} & - & - & - & 0.08 \\
\hline & - & - & - & {$[5.93]^{* *}$} \\
\hline \multirow[t]{2}{*}{ Member of trade union/business } & - & - & - & 0.13 \\
\hline & - & - & - & {$[9.02]^{* *}$} \\
\hline \multirow[t]{2}{*}{ Member of self-help } & - & - & - & -0.07 \\
\hline & - & - & - & {$[-6.45]^{* *}$} \\
\hline \multirow[t]{2}{*}{ Member of credit/savings } & - & - & - & 0.06 \\
\hline & - & - & - & {$[5.44]^{* *}$} \\
\hline \multirow{2}{*}{ Member of religion/social } & - & - & - & 0.07 \\
\hline & - & - & - & {$[7.88]^{* *}$} \\
\hline \multirow[t]{2}{*}{ Member of caste association } & - & - & - & 0.04 \\
\hline & - & - & - & {$[4.47]^{* *}$} \\
\hline \multirow[t]{2}{*}{ Member of development/NGO } & - & - & - & 0.20 \\
\hline & - & - & - & {$[9.34]^{* *}$} \\
\hline \multirow[t]{2}{*}{ Member of cooperative } & - & - & - & 0.10 \\
\hline & - & - & - & {$[6.29]^{* *}$} \\
\hline \multirow[t]{2}{*}{ Member of political network } & - & - & - & 0.05 \\
\hline & - & - & - & {$[5.25]^{* *}$} \\
\hline \multirow[t]{2}{*}{ Settlement (= I if urban) } & 0.37 & 0.37 & 0.37 & 0.36 \\
\hline & {$[52.77]^{* *}$} & {$[53.25]^{* *}$} & {$[53.35]^{* *}$} & {$[51.61]^{* *}$} \\
\hline \multirow{2}{*}{$\begin{array}{l}\text { Dependency ratio (number of } \\
\text { infants) }\end{array}$} & -0.06 & -0.06 & -0.06 & -0.06 \\
\hline & {$[-17.80]^{* *}$} & {$[-17.66]^{* *}$} & {$[-17.62]^{* *}$} & {$[-17.69]^{* *}$} \\
\hline \multirow[t]{2}{*}{ Household size } & -0.09 & -0.09 & -0.09 & -0.09 \\
\hline & {$[-46.73]^{* *}$} & {$[-46.70]^{* *}$} & {$[-46.74]^{* *}$} & {$[-46.8 I]^{* *}$} \\
\hline $\begin{array}{l}\text { Working members in } \\
\text { household (number of }\end{array}$ & 0.04 & 0.04 & 0.04 & 0.04 \\
\hline adults) & {$[13.00]^{* *}$} & {$[12.54]^{* *}$} & {$[12.60]^{* *}$} & {$[12.66]^{* *}$} \\
\hline
\end{tabular}


Table 2. (Continued)

\begin{tabular}{|c|c|c|c|c|}
\hline \multirow[t]{2}{*}{ Explanatory variables } & \multicolumn{3}{|c|}{ Least squares estimation } & \multirow{2}{*}{$\begin{array}{l}\text { Type of } \\
\text { network } \\
\text { affiliated to } \\
\text { household }\end{array}$} \\
\hline & $\begin{array}{l}\text { Whether } \\
\text { household is } \\
\text { affiliated to a } \\
\text { social network }\end{array}$ & $\begin{array}{l}\text { Number of } \\
\text { networks } \\
\text { affiliated to } \\
\text { household }\end{array}$ & $\begin{array}{l}\text { Square of } \\
\text { the number } \\
\text { of networks }\end{array}$ & \\
\hline \multirow{2}{*}{ Religion (= I if Muslim) } & -0.04 & -0.05 & -0.05 & -0.05 \\
\hline & {$[-5.14]^{* *}$} & {$[-5.29]^{* *}$} & {$[-5.32]^{* *}$} & {$[-5.77]^{* *}$} \\
\hline \multirow{2}{*}{$\begin{array}{l}\text { Sex of household head } \\
(=I \text { if male })\end{array}$} & 0.03 & 0.03 & 0.03 & 0.03 \\
\hline & {$[2.57]^{*}$} & {$[2.62]^{* *}$} & {$[2.57]^{*}$} & {$[2.61]^{* *}$} \\
\hline $\begin{array}{l}\text { Scheduled caste/tribe }(=I \text { if } \\
\text { household }\end{array}$ & -0.22 & -0.22 & -0.22 & -0.21 \\
\hline $\begin{array}{l}\text { belongs to scheduled caste } \\
\text { or tribe) }\end{array}$ & {$[-33.83]^{* *}$} & {$[-34.09]^{* *}$} & {$[-34.09]^{* *}$} & {$[-33.65]^{* *}$} \\
\hline \multirow[t]{2}{*}{ BIMARU $^{2,3}$} & -0.46 & -0.46 & -0.46 & -0.47 \\
\hline & {$[-49.27]^{* *}$} & {$[-49.59]^{* *}$} & {$[-49.63]^{* *}$} & {$[-50.02]^{* *}$} \\
\hline \multirow[t]{2}{*}{ South ${ }^{4}$} & -0.38 & -0.39 & -0.39 & -0.38 \\
\hline & {$[-43.11]^{* *}$} & {$[-44.23]^{* *>}$} & {$[-44.33]^{* *}$} & {$[-43.41]^{* *}$} \\
\hline \multirow[t]{2}{*}{ East $^{5}$} & -0.59 & -0.59 & -0.60 & -0.60 \\
\hline & {$[-6|.3|]^{* *}$} & {$[-61.84]^{* *}$} & {$[-61.95]^{* *}$} & {$[-62.29]^{* *}$} \\
\hline \multirow{2}{*}{ Others $^{6}$} & -0.17 & -0.17 & -0.17 & -0.17 \\
\hline & {$[-9.73]^{* *}$} & {$[-10.11]^{* *}$} & {$[-10.09]^{* *}$} & {$[-10.05]^{* *}$} \\
\hline $\begin{array}{l}\text { Number of household } \\
\text { members with at least }\end{array}$ & 0.21 & 0.20 & 0.20 & 0.20 \\
\hline higher secondary education) & {$[56.43]^{* *}$} & {$[56.14]^{* *}$} & {$[56.10]^{* *}$} & {$[55.68]^{* *}$} \\
\hline $\begin{array}{l}\text { Land ownership (= I if } \\
\text { household owns agric. }\end{array}$ & 0.09 & 0.10 & 0.10 & 0.10 \\
\hline land) & {$[14.23]^{* *}$} & {$[14.66]^{* *}$} & {$[|4.5|]^{* *}$} & {$[14.49]^{* *}$} \\
\hline \multirow[t]{2}{*}{ Constant } & 7.09 & 7.10 & 7.10 & 7.11 \\
\hline & {$[493.41]^{* *}$} & {$[494.29]^{* *}$} & {$[494.26]^{* *}$} & {$[494.66]^{* *}$} \\
\hline$N$ & 41,237 & 41,237 & $4 I, 237$ & $4 \mid, 012$ \\
\hline Adj. $R^{2}$ & 0.390 & 0.392 & 0.393 & 0.397 \\
\hline F-statistics & 1550.93 & 1558.98 & |457.7| & 1012.19 \\
\hline Log likelihood & $-3.4 e+04$ & $-3.4 e+04$ & $-3.4 e+04$ & $-3.4 e+04$ \\
\hline
\end{tabular}

Notes: $t$ statistics in brackets $-+p<.10, * p<.05, * * p<.01$.

'Reference group for type of social network is member of Mahila Mandal.

${ }^{2}$ BIMARU is a dummy variable that takes I for BIMARU states (Bihar, Madhya Pradesh, Rajasthan and Uttar Pradesh).

${ }^{3}$ Reference category is North.

${ }^{4}$ South states are Gujarat, Maharathra, Andhra Pradesh, Karnataka, Kerala, Tamil Nadu and Pondicherry.

${ }^{5}$ East states are Sikkim, Arunachal Pradesh, Nagaland, Manipur, Mizoram, Tripura, Meghalaya, Assam, West

Bengal Jharkhand, Orissa and Chhatisgarh.

${ }^{6}$ Other states are Delhi, Goa, Daman \& Diu and Dadra+Nagar Haveli.

per capita with important implications for joining networks. For example, household residents in urban areas have a higher consumption per capita than their rural counterparts, and households with a greater number of relatively more educated members are 
able to increase their consumption per capita by about 20 per cent. Finally, larger household sizes and the number of infants (an indicator of the dependency ratio) are observed to reduce the consumption per capita by approximately 9 and 6 per cent respectively. Appendix Table 3 shows similar results for the case of logit estimation.

The results of the IV estimation alongside the reduced form model (first stage) are presented in Table 3. As already mentioned, the instrument used to address potential bicausality between a household, number of social networks, capital and poverty is the number of social networks and other recreational facilities in a village. The first-stage regression confirms that one of the conditions in identifying an instrument as the coefficient of a number of social networks and other recreational facilities in a village in the household number of social networks equation is statistically significant. The IV estimation shows that the number of social networks has a positive effect on consumption per capita by a higher magnitude of approximately 21 per cent compared to OLS (this is the same as the $20 \%$ finding in Table 2). Comparing the effect of all the other explanatory variables in the IV estimation with the OLS, the signs and magnitudes do not vary across these two estimations.

To verify the strength of the instruments, we present results for both under- and weak identification. In both cases, the respective null hypothesis of the instrument being underidentified and the model being weakly identified are rejected. Furthermore, the test of endogeneity confirms the theoretical position that social networks and poverty are bicausally related. Finally, the Durbin-Wu-Hausman test rejects the hypothesis that the OLS yields consistent estimates. On this note, we assert that an additional increase in the number of social networks that a household is affiliated to causes consumption per capita to increase by approximately 21 per cent. In general our findings show that changes in consumption are also determined by the type and number of networks, as the number of social networks is observed to be positively associated with monthly per capita consumption expenditure. Of course, not all networks provide equal benefits as households with at least one member affiliated with a development agency or an NGO is likely to increase its consumption by 20 per cent, those with political networks increase by 5 per cent and those with affiliation in a caste-related network are able to increase consumption expenditure by only 4 per cent. More surprisingly the impact of women-based SHG membership on household consumption is negative. This could suggest that networks through bonding capital, for example, among homogenous or closed groups may provide the same level of information among members which may have no impact on their household consumption; rather, bridging networks across social groups may improve social relations based on norms and networks that spill over to the household, community and wider society, and enhance resource flow to households for improved consumption behaviour.

The negative impact of female-based SHG membership on household consumption is initially puzzling, but less surprising given the emergent buzz around micro-credit and women's empowerment. In the Indian state of Andhra Pradesh, Deininger (2013) shows how approaches that combine micro-credit with efforts to address specific needs of the poor to enhance their economic potential show benefits in empowerment and nutritional intake, with some consumption smoothing and income diversification but not asset formation. Evidence on the benefits of such SHG membership of women themselves is 
Table 3. Robust instrument variable estimation of the effect of social networks on poverty.

\begin{tabular}{|c|c|c|}
\hline \multirow[t]{3}{*}{ Explanatory variables } & \multicolumn{2}{|l|}{ Dependent variable } \\
\hline & \multirow{2}{*}{$\begin{array}{l}\text { Number of social networks } \\
\text { affiliated to household } \\
\text { First-stage estimation }\end{array}$} & \multirow{2}{*}{$\begin{array}{l}\text { Log of consumption per } \\
\text { capita } \\
\text { Second-stage estimation }\end{array}$} \\
\hline & & \\
\hline \multirow{2}{*}{$\begin{array}{l}\text { Number of social networks in } \\
\text { village (instrument) }\end{array}$} & 0.07 & - \\
\hline & {$[22.01]^{* *}$} & - \\
\hline \multirow{2}{*}{$\begin{array}{l}\text { Number of social networks } \\
\text { affiliated to household }\end{array}$} & - & 0.21 \\
\hline & - & {$[9.88]^{* *}$} \\
\hline \multirow[t]{2}{*}{ Settlement (= I if urban) } & 0.10 & 0.41 \\
\hline & {$[5.31]^{* *}$} & {$[46.8 \mathrm{I}]^{* *}$} \\
\hline \multirow{2}{*}{$\begin{array}{l}\text { Dependency ratio (number of } \\
\text { infants) }\end{array}$} & -0.05 & -0.05 \\
\hline & {$[-6.42]^{* *}$} & {$[-13.70]^{* *}$} \\
\hline \multirow[t]{2}{*}{ Household size } & 0.02 & -0.10 \\
\hline & {$[6.03]^{* *}$} & {$[-44.60]^{* *}$} \\
\hline \multirow{2}{*}{$\begin{array}{l}\text { Working members in } \\
\text { household (number of adults) }\end{array}$} & 0.04 & 0.03 \\
\hline & {$[5.62]^{* *}$} & {$[9.25]^{* *}$} \\
\hline \multirow[t]{2}{*}{ Religion (= I if Muslim) } & 0.06 & -0.06 \\
\hline & {$[3.30]^{* *}$} & {$[-6.04]^{* *}$} \\
\hline \multirow{2}{*}{$\begin{array}{l}\text { Sex of household head }(=1 \text { if } \\
\text { male) }\end{array}$} & 0.04 & 0.02 \\
\hline & {$[2.30]^{*}$} & {$[1.91]+$} \\
\hline \multirow{2}{*}{$\begin{array}{l}\text { Scheduled caste/tribe }(=\mathrm{I} \text { if } \\
\text { household belongs to scheduled } \\
\text { caste or tribe) }\end{array}$} & 0.05 & -0.22 \\
\hline & {$[3.66]^{* *}$} & {$[-32.76]^{* *}$} \\
\hline \multirow[t]{2}{*}{ BIMARU ${ }^{\prime, 2}$} & 0.12 & -0.48 \\
\hline & {$[8.26]^{* *}$} & {$[-48.50]^{* *}$} \\
\hline \multirow[t]{2}{*}{ South $^{3}$} & 0.64 & -0.52 \\
\hline & {$[38.78]^{* *}$} & {$[-27.78]^{* *}$} \\
\hline \multirow[t]{2}{*}{ East $^{4}$} & 0.45 & -0.67 \\
\hline & {$[26.86]^{* *}$} & {$[-47.17]^{* *}$} \\
\hline \multirow{2}{*}{ Others ${ }^{5}$} & 0.00 & -0.18 \\
\hline & {$[0.03]$} & {$[-10.52]^{* *}$} \\
\hline \multirow{2}{*}{$\begin{array}{l}\text { Number of household members } \\
\text { with at least higher secondary } \\
\text { education) }\end{array}$} & 0.08 & 0.19 \\
\hline & {$[10.87]^{* *}$} & {$[45.82]^{* *}$} \\
\hline \multirow{2}{*}{$\begin{array}{l}\text { Land ownership (= I if } \\
\text { household owns agric. land) }\end{array}$} & 0.14 & 0.08 \\
\hline & {$[9.77]^{* *}$} & {$[11.60]^{* *}$} \\
\hline
\end{tabular}


Table 3. (Continued)

\begin{tabular}{|c|c|c|}
\hline \multirow[t]{3}{*}{ Explanatory variables } & \multicolumn{2}{|l|}{ Dependent variable } \\
\hline & \multirow{2}{*}{$\begin{array}{l}\text { Number of social networks } \\
\text { affiliated to household } \\
\text { First-stage estimation }\end{array}$} & \multirow{2}{*}{$\begin{array}{l}\text { Log of consumption per } \\
\text { capita } \\
\text { Second-stage estimation }\end{array}$} \\
\hline & & \\
\hline \multirow{2}{*}{ Constant } & -0.19 & 7.09 \\
\hline & {$[-6.99]^{* *}$} & {$[472.26]^{* *}$} \\
\hline$N$ & 40,658 & 40,596 \\
\hline Adj. $R^{2}$ & 0.105 & 0.333 \\
\hline F-statistics & 294.75 & 1429.05 \\
\hline Log likelihood & $-6.3 e+04$ & $-3.5 e+04$ \\
\hline \multicolumn{3}{|c|}{ Post-estimation test for instrumental variable estimation } \\
\hline Traditional Hausman & - & $65.10(0.00)$ \\
\hline Under-identification test & - & $652.06(0.00)$ \\
\hline Weak identification test & - & $662.46(0.00)$ \\
\hline Durbin-Wu-Hausman & - & $66.57(0.00)$ \\
\hline
\end{tabular}

Notes: $t$ statistics in brackets $-+p<.10,{ }^{*} p<.05,{ }^{*} p<.01$. Reference group for type of social network is member of Mahila Mandal.

'BIMARU is a dummy variable that takes I for BIMARU states (Bihar, Madhya Pradesh, Rajasthan and Uttar Pradesh).

${ }^{2}$ Reference category is North.

${ }^{3}$ South states are Gujarat, Maharathra, Andhra Pradesh, Karnataka, Kerala, Tamil Nadu and Pondicherry.

${ }^{4}$ East states are Sikkim, Arunachal Pradesh, Nagaland, Manipur, Mizoram, Tripura, Meghalaya, Assam, West

Bengal Jharkhand, Orissa and Chhatisgarh.

${ }^{5}$ Other states are Delhi, Goa, Daman \& Diu and Dadra+Nagar Haveli.

questionable as Garikipati (2012) argues that women's loans through SHGs are often used to benefit their men, by enhancing male ownership of the household's productive assets, showing little control on loan-created assets; while Balasubramanian (2013) argues that women within households are worse off with micro-credit.

Furthermore, the additional increase in the number of social networks that a household is affiliated to also causes consumption per capita to rise. That is, the number of social networks per se has a positive effect on consumption per capita. Thus, the type of network and strength of ties has an important bearing on the information generated and exchanged, particularly as gender plays a key role, creating both weak and strong ties through homogenous self-help groups with women from similar backgrounds, but also other kinds of network where trust and reciprocity are important for developing such community-based solidarity. Participation in such networks has improved levels of well-being through awareness, information source, resource sharing and resilience against vulnerability.

\section{Conclusions}

This article sets out to explore the effect of social networks as a vital component of the household asset base on consumption levels among households in India. Using IHDS 
data, the findings indicate that households with participation in social networks improved their consumption levels, showing the possibilities of social mobility leading to overall well-being and improved welfare. We were also informed by a range of determinants for social networks that impacted on consumption per capita such as region, social grouping, urban-rural residence and educational status. Our findings show that penetration of households into the different types of network is quite high across regions in India, with two out of every five households having at least one member belonging to a social network.

However, not all networks lead to the same conclusion; this is an interesting observation whereby membership of different networks yields varying outcomes of consumption. This is perhaps because groups formed on the basis of social identity such as caste may focus on social rights or justice rather than on improving economic gains. However, bridging networks across social groups may improve social relations based on norms and networks that spill over to the household, community and wider society. The negative impact of a women-based SHG membership on household consumption needs further probing, given the emergent buzz around micro-credit and women's empowerment.

Further, our findings show that states in the southern area constitute more than half of the households with at least one member affiliated with a social network. Less than a quarter of households with social network affiliation are residing in urban areas, which may pinpoint rural-urban disparities in the distribution of social networks as well as higher participation of households. Further, those with higher human capital levels, such as education, also seemed to improve their consumption patterns through such social affiliations. There is some encouraging evidence that the Human Development Index and its component indices have shown convergence across states as the poorer states with a high concentration of various marginalised groups are catching up with the national average; this strongly suggests that these groups are starting to share the benefits of the process of human development, particularly through good governance and massive social mobilisation (GOI, 2011).

One of the major findings - that 80 per cent of households affiliated to a social network are above the poverty line - corroborates the evidence that networking is often more extensive among upwardly mobile groups; Christakis and Fowler (2010) suggest that levels of personal well-being directly relate to position in social network chains. This could also be suggestive of the causal relationship between membership of networks and impact on welfare or vice versa, as Vanneman et al. (2006) suggest that networking is extensive among advantaged groups, suggestive of resource monopoly by the well-off (e.g Blokland and Savage, 2008). This is supported by our finding that those with political networks also see an increase in consumption, showing their gainful position within such networks. The study finds that participating in the number and nature of social networks is critical in enhancing an environment through which specific social groups can strengthen life choices through improved consumption levels, well-being and social mobility.

\section{Acknowledgements}

We are grateful to the Brooks World Poverty Insitute, at the University of Manchester and Dr Barbara Evers for comments on an earlier version of the article. 


\section{Funding}

This research received no specific grant from any funding agency in the public, commercial or not-for-profit sectors.

\section{Notes}

1. Mahila Mandalas are voluntary organisations in India aimed at women's progress in society through providing basic needs such as health, nutrition, education and family welfare, as well improving economic benefits through savings groups and economic activities.

2. Political network is based on whether somebody in the household or close to the household is an official of the village panchayat/nagarpalika/ward (local administrative units) committee.

\section{References}

Andreotti A (2006) Coping strategies in a wealthy city of northern Italy. International Journal of Urban and Regional Research 30(2): 328-345.

Arun S, Annim S and Arun T (2013) Overcoming household shocks: Do asset-accumulation strategies matter? Review of Social Economy 71(3): 281-305.

Balasubramanian S (2013) Why micro-credit may leave women worse off: Non-cooperative bargaining and the marriage game in South Asia. Journal of Development Studies 49(5): $609-623$.

Bebbington A (1999) Capitals and capabilities: A framework for analyzing peasant viability, rural livelihoods and poverty. World Development 27(12): 2021-2044.

Bhattacharyya M, Bedi AS and Chhachhi A (2011) Marital violence and women's employment and property status: Evidence from north Indian villages. World Development 39(9): 1676-1689.

Blau PM (1967) Exchange and Power in Social Life. London: John Wiley and Sons.

Blokland T and Savage M (2008) Networked Urbanism: Social Capital in the City. Farnham: Ashgate.

Borooah VK (2010) Inequality in health outcomes in India, the role of caste and religion. In: Thorat S and Newman K (eds) Blocked by Caste: Economic Discrimination in Modern India. New Delhi: Oxford University Publishing.

Bourdieu P and Wacquant L (1992) An Invitation to Reflexive Sociology. Cambridge: Polity Press. Briggs X (2005) Social capital and segregation in the United States. In: Varady L (ed.) Desegregating the City. New York: SUNY Press.

Caldeira T (2001) City of Walls. Berkeley, CA: University of California Press.

Chantarat S and Barrett B (2012) Social network capital, economic mobility and poverty traps. Journal of Economic Inequality 10(3): 299-342.

Christakis N and Fowler J (2010) Connected: The Amazing Power of Social Networks and How They Shape Our Lives. London: Harper Press.

Collier P (2002) Social capital and poverty: A microeconomic perspective. In: Grootaert C and Van Bastelaer T (eds) Role of Social Capital in Development: An Empirical Assessment. West Nyack, NY: Cambridge University Press, 19-41.

Costa DL and Kahn ME (2001) Understanding the Decline in Social Capital, 1952-1998. NBER Working Paper 8295. Cambridge, MA: National Burueau of Economic Research.

Deininger K (2013) Economic and social impacts of an innovative self-help group model in India. World Development 43: 149-163.

Dolfsma W and Dannreuther C (2003) Subjects and boundaries: Contesting social capital-based policies. Journal of Economic Issues 37(2): 405-413.

Doss C (2006) The effects of intrahousehold property ownership on expenditure patterns in Ghana. Journal of African Economies 15(1): 149-180. 
Durbin S (2011) Creating knowledge through networks: A gender perspective. Gender, Work and Organisation 18(1): 90-112.

Fedderke J, De Kadt R and Luiz J (1999) Economic growth and social capital: A critical reflection. Theory and Society 28(5): 709-745.

Friedemann-Sánchez G (2006) Assets in intrahousehold bargaining among women workers in Colombia's cut-flower industry. Feminist Economics 12(1\&2): 247-269.

Fukuyama F (1999) Trust: The Social Virtues and the Creation of Prosperity. New York: Free Press.

Garikipati S (2012) Microcredit and women's empowerment: Through the lens of time-use data from rural India. Development and Change 43(3): 719-750.

Gilchrist A and Kyprianou P (2011) Social networks, poverty and ethnicity. Joseph Rowntree Foundation. Available at: www.jrf.org.uk/sites/files/jrf/poverty-ethnicity-social-networksfull.pdf (accessed 10 October 2011).

Gittel R and Vidal A (1998) Community Organising: Building Social Capital as a Development Strategy. Los Angeles, CA: SAGE.

Godinot X, Hyberger C, Heyberger P, et al. (2007) Resisting extreme poverty: Learning from families in Burkina Faso and Peru. In: Narayan D and Petesch P (eds) Moving Out of Poverty. Cross-Disciplinary Perspectives on Mobility. Washington, DC and Basingstoke: World Bank and Palgrave Macmillan, 273-306.

Government of India (GOI) (2011) India Human Development Report: Towards Social Inclusion. New Delhi: Government of India, Institute of Applied Manpower Research, Planning Commission.

Granovetter MS (1973) The strength of weak ties. American Journal of Sociology 78(6): 13601380.

Halpern D (2005) Social Capital. Cambridge: Polity Press.

Heller P (1996) Social capital as a product of class mobilization and state intervention: Industrial workers in Kerala, India. World Development 24(6): 1055-1071.

Krishna A and Uphoff N (1999) Mapping and Measuring Social Capital: A Conceptual and Empirical Study of Collective Action for Conserving and Developing Watersheds in Rajasthan, India. Social Capital Initiative Working Paper 13. Washington, DC: World Bank.

Marques E (2011) Social networks, segreation and poverty in Sao Paulo. International Journal of Urban and Regional Research 36(5): 958-979.

Moser C and Dani A (2008) Assets, Livelihoods and Social Policy. Washington, DC: World Bank. NABARD (2012) Status of Micro-Finance in India 2011-12. Mumbai, India: National Bank for Agricultural and Rural Development. Available at: http://indiamicrofinance.com/wp-content/ uploads/2012/11/Status-of-Microfinance-2011-12.pdf (accessed 29 April 2015).

Narayan D and Pritchett L (1999) Cents and sociability: Household income and social capital in rural Tanzania. Economic Development and Cultural Change 47(4): 871-897.

Paldam M (2000) Social capital: One or many definition and measurement. Journal of Economic Surveys 14(5): 629-653.

Panda P and Agarwal B (2005) Marital violence, human development and women's property status in India. World Development 33(5): 823-850.

Perlman JE (2007) Elusive pathways out of poverty: Intra and intergenerational mobility in the favelas of Rio Janeiro. In: Narayan D and Petesch P (eds) Moving Out of Poverty: CrossDisciplinary Perspectives on Mobility. Washington, DC and Basingstoke: World Bank and Palgrave Macmillan, 227-272.

Portes A (ed.) (1995) The Economic Sociology of Immigration: Essays on Networks, Ethnicity, and Entrepreneurship. New York: Russell Sage Foundation. 
Portes A (1998) Social capital: Its origins and applications in modern sociology. Annual Review of Sociology 24: 1-24.

Putnam RD (1993) Making Democracy Work: Civic Traditions in Modern Italy. Princeton, NJ: Princeton University Press.

Putnam RD (2000) Bowling Alone: The Collapse and Revival of American Community. New York: Simon and Schuster.

Raja Reddy K and Reddy CS (2012) Self Help Groups in India: A Study on Quality and Sustainability. Hyderabad: ENABLE Publication.

Shanker S and Gaiha R (2011) Networks and Anti-Poverty Programs: The NREG Experience. ASARC Working Paper 2011/5. Canberra: Australia National University.

Stock JH and Yogo M (2005) Testing for weak instruments in linear IV regression. In: Stock JH and Andrews DWK (eds) Identification and Inference for Econometric Models: Essays in Honour of Thomas J. Rothenberg. New York: Cambridge University Press, 80-108.

Thorat A (2010) Ethnicity, caste and religion: Implications for poverty outcome. Economic and Political Weekly 45(51): 47-53.

Trinies V, Freeman MC, Hennink M, et al. (2011) The role of social networks on the uptake of household water filters by women in self-help groups in rural India. Journal of Water, Sanitation and Hygiene for Development 1(4): 224-232.

Vanneman R, Noon J, Sen M, et al. (2006) Social Networks in India: Caste, Tribe, and Religious Variations. Indian Human Development Studies (IHDS) Working Paper 3. New Delhi and Maryland: NCAER and The University of Maryland. Available at: http://www.ihds.umd.edu/ IHDS_papers/Networks.pdf.

Warde A and Tampubolon G (2002) Social capital, networks and leisure consumption. Sociological Review 50(2): 155-181.

Wetherell M (ed.) (2009) Theorizing Identities and Social Action. Basingstoke: Palgrave.

Wooldridge J (2009) Introductory Econometrics: A Modern Approach. Mason, OH: South Western Educational Publishing.

Shoba Arun is Senior Lecturer in the Department of Sociology, Manchester Metropolitan University. As an economic sociologist, her research interests relate to comparative and global issues of socio-economic inequalities, including gender and social divisions in relation to the household and labour market.

Samuel Annim is Associate Professor of Economics at the University of Cape Coast, Ghana and a research associate at the Lancashire Business School, University of Central Lancashire, UK. His areas of research are microfinance and households' health and finance decision-making issues. In addition to publication-oriented research, he has undertaken consultancy services for international organizations such as IFAD and the World Bank on issues related to poverty and microfinance.

Thankom Arun is Professor of Development Finance and Public Policy at the University of Central Lancashire, UK and Professor Extraordinary at the University of Stellenbosch, South Africa. $\mathrm{He}$ has worked largely on both macro and micro aspects of finance and development, mostly in Asia and Africa, combining quantitative and qualitative research approaches.

Date submitted July 2014

Date accepted February 2015 


\section{Appendices}

Table I. Summary statistics.

\begin{tabular}{|c|c|c|c|c|c|}
\hline Variable & Obs. & Mean & SD & Min & Max \\
\hline Log of consumption per capita & $4 I, 237$ & 6.58 & 0.71 & 1.39 & 10.58 \\
\hline$=\mathrm{I}$ if household is below poverty line & 41,237 & 0.20 & 0.40 & 0 & I \\
\hline Number of networks affiliated to household & $4 I, 237$ & 0.77 & 1.21 & 0 & 10 \\
\hline Settlement (= I if urban) & 41,237 & 0.36 & 0.48 & 0 & I \\
\hline Dependency ratio (number of infants) & $4 I, 237$ & 0.59 & 0.90 & 0 & 9 \\
\hline Household size & $4 I, 237$ & 5.19 & 2.49 & I & 38 \\
\hline Number of adults & 41,237 & 2.80 & 1.38 & 0 & 18 \\
\hline$=\mathrm{I}$ if dominant religion in household is Muslim & 41,237 & 0.11 & 0.32 & 0 & I \\
\hline Sex of household head (= I if male) & 41,237 & 0.90 & 0.30 & 0 & I \\
\hline$=\mathrm{I}$ if households belong to scheduled caste or tribe & $4 I, 237$ & 0.28 & 0.45 & 0 & 1 \\
\hline Location & 41,237 & 2.73 & 1.02 & 1 & 5 \\
\hline $\begin{array}{l}\text { Number of household members with at least higher } \\
\text { secondary education }\end{array}$ & $4 I, 237$ & 0.55 & 1.00 & 0 & 10 \\
\hline$=\mathrm{I}$ if household own agricultural land & $4 I, 237$ & 0.42 & 0.49 & 0 & 1 \\
\hline Number networks in the village & 40,913 & 3.11 & 3.37 & 0 & 13 \\
\hline
\end{tabular}

Table 2. Classification of location by proportion of households below poverty line.

\begin{tabular}{lc}
\hline Location & Proportion of households below poverty line \\
\hline North & 3.91 \\
BIMARU & 34.89 \\
South & 28.20 \\
East & 32.24 \\
Others & 0.75 \\
Total & 100 \\
\hline
\end{tabular}


Table 3. Robust regression results of the effect of social network on poverty ( $=\mathrm{I}$ if household is below the poverty line).

\begin{tabular}{|c|c|c|c|}
\hline \multirow[t]{2}{*}{ Explanatory variables } & \multicolumn{3}{|l|}{ Logit estimation } \\
\hline & $\begin{array}{l}\text { Whether household } \\
\text { is affiliated to a social } \\
\text { network }\end{array}$ & $\begin{array}{l}\text { Number of } \\
\text { networks affiliated } \\
\text { to household }\end{array}$ & $\begin{array}{l}\text { Type of network } \\
\text { affiliated to } \\
\text { household }\end{array}$ \\
\hline \multirow{2}{*}{$\begin{array}{l}\text { Dummy for social network (= I if } \\
\text { a household member belongs to at } \\
\text { least one network) }\end{array}$} & -0.35 & - & - \\
\hline & {$[-11.83]^{* *}$} & - & - \\
\hline \multirow[t]{2}{*}{ Number of social network } & - & -0.17 & - \\
\hline & - & {$[-12.11]^{* *}$} & - \\
\hline \multirow[t]{2}{*}{ Member of youth/sports/read 7} & - & - & 0.07 \\
\hline & - & - & {$[0.96]$} \\
\hline \multirow[t]{2}{*}{ Member of trade union/business } & - & - & -0.20 \\
\hline & - & - & {$[-2.70]^{* *}$} \\
\hline \multirow[t]{2}{*}{ Member of self help } & - & - & 0.24 \\
\hline & - & - & {$[4.94]^{* *}$} \\
\hline \multirow[t]{2}{*}{ Member of credit/savings } & - & - & -0.20 \\
\hline & - & - & {$[-3.30]^{* *}$} \\
\hline \multirow[t]{2}{*}{ Member of religion/social } & - & - & -0.32 \\
\hline & - & - & {$[-6.7 I]^{* *}$} \\
\hline \multirow[t]{2}{*}{ Member of caste assoc. } & - & - & -0.23 \\
\hline & - & - & {$[-4.84]^{* *}$} \\
\hline \multirow[t]{2}{*}{ Member of development/NGO } & - & - & -0.88 \\
\hline & - & - & {$[-6.13]^{* *}$} \\
\hline \multirow{2}{*}{ Member of cooperative } & - & - & -0.60 \\
\hline & - & - & {$[-5.82]^{* *}$} \\
\hline \multirow[t]{2}{*}{ Member of political network } & - & - & -0.19 \\
\hline & - & - & {$[-4.00]^{* *}$} \\
\hline \multirow[t]{2}{*}{ Settlement (= I if urban) } & 0.19 & 0.19 & 0.20 \\
\hline & {$[5.62]^{* *}$} & {$[5.45]^{* *}$} & {$[5.86]^{* *}$} \\
\hline \multirow{2}{*}{$\begin{array}{l}\text { Dependency ratio (number of } \\
\text { infants) }\end{array}$} & 0.23 & 0.23 & 0.23 \\
\hline & {$[|3.6|]^{* *}$} & {$[13.54]^{* *}$} & {$[13.40]^{* *}$} \\
\hline \multirow[t]{2}{*}{ Household size } & 0.27 & 0.27 & 0.28 \\
\hline & {$[29.03]^{* * *}$} & {$[28.99]^{* *}$} & {$[29.35]^{* *}$} \\
\hline \multirow{2}{*}{$\begin{array}{l}\text { Number of working adults in } \\
\text { household }\end{array}$} & -0.17 & -0.17 & -0.17 \\
\hline & {$[-10.89]^{* *}$} & {$[-10.61]^{* *}$} & {$[-10.84]^{* *}$} \\
\hline \multirow[t]{2}{*}{ Religion (= I if Muslim) } & 0.23 & 0.23 & 0.27 \\
\hline & {$[5.30]^{* *}$} & {$[5.42]^{* *}$} & {$[6.12]^{* *}$} \\
\hline \multirow{2}{*}{$\begin{array}{l}\text { Sex of household head }(=1 \text { if } \\
\text { male) }\end{array}$} & -0.13 & -0.13 & -0.13 \\
\hline & {$[-2.75]^{* *}$} & {$[-2.83]^{* *}$} & {$[-2.8 I]^{* *}$} \\
\hline \multirow{2}{*}{$\begin{array}{l}\text { Scheduled caste/tribe }(=1 \text { if } \\
\text { household belongs to scheduled } \\
\text { caste or tribe) }\end{array}$} & 0.75 & 0.75 & 0.76 \\
\hline & {$[24.69]^{* *}$} & {$[24.87]^{* *}$} & {$[24.88]^{* *}$} \\
\hline
\end{tabular}


Table 3. (Continued)

\begin{tabular}{|c|c|c|c|}
\hline \multirow[t]{2}{*}{ Explanatory variables } & \multicolumn{3}{|l|}{ Logit estimation } \\
\hline & $\begin{array}{l}\text { Whether household } \\
\text { is affiliated to a social } \\
\text { network }\end{array}$ & $\begin{array}{l}\text { Number of } \\
\text { networks affiliated } \\
\text { to household }\end{array}$ & $\begin{array}{l}\text { Type of network } \\
\text { affiliated to } \\
\text { household }\end{array}$ \\
\hline \multirow[t]{2}{*}{ BIMARU2,3 } & 1.50 & 1.51 & 1.58 \\
\hline & {$[25.19]^{* *}$} & {$[25.27]^{\text {*** }}$} & {$[25.88]^{* *}$} \\
\hline \multirow[t]{2}{*}{ South ${ }^{4}$} & 1.18 & 1.20 & 1.21 \\
\hline & {$[19.61]^{* *}$} & {$[19.90]^{* *}$} & {$[19.71]^{* *}$} \\
\hline \multirow[t]{2}{*}{ East $^{5}$} & 1.89 & 1.89 & 1.96 \\
\hline & {$[31.13]^{* *}$} & {$[31.16]^{* *}$} & {$[31.62]^{* *}$} \\
\hline \multirow[t]{2}{*}{ Others $^{6}$} & 0.60 & 0.62 & 0.67 \\
\hline & {$[5.13]^{* *}$} & {$[5.28]^{* *}$} & {$[5.71]^{* *}$} \\
\hline \multirow{2}{*}{$\begin{array}{l}\text { Number of household members } \\
\text { with at least higher secondary } \\
\text { education }\end{array}$} & $-0.7 I$ & -0.70 & -0.72 \\
\hline & {$[-25.57]^{* *}$} & {$[-25.46]^{* *}$} & {$[-25.68]^{* * *}$} \\
\hline \multirow{2}{*}{$\begin{array}{l}\text { Land ownership (= I if } \\
\text { household owns agricultural } \\
\text { land) }\end{array}$} & -0.25 & -0.26 & -0.25 \\
\hline & {$[-7.72]^{* *}$} & {$[-7.97]^{* *}$} & {$[-7.66]^{* *}$} \\
\hline \multirow[t]{2}{*}{ Constant } & -3.60 & -3.63 & -3.72 \\
\hline & {$[-44.25]^{* *}$} & {$[-44.53]^{* *}$} & {$[-44.94]^{* *}$} \\
\hline$N$ & 41,299 & 41,299 & $4 I, 051$ \\
\hline Log likelihood & $-1.7 e+04$ & $-1.7 e+04$ & $-1.7 e+04$ \\
\hline
\end{tabular}

Notes

't statistics in brackets $-+p<.10, * p<.05, * * p<.01$.

2BIMARU is a dummy variable that takes I for BIMARU states (Bihar, Madhya Pradesh, Rajasthan and Uttar Pradesh).

${ }^{3}$ Reference category is North.

${ }^{4}$ South states are Gujarat, Maharathra, Andhra Pradesh, Karnataka, Kerala, Tamil Nadu and Pondicherry. ${ }^{5}$ East states are Sikkim, Arunachal Pradesh, Nagaland, Manipur, Mizoram, Tripura, Meghalaya, Assam, West Bengal Jharkhand, Orissa and Chhatisgarh.

${ }^{6}$ Other states are Delhi, Goa, Daman \& Diu and Dadra+Nagar Haveli.

${ }^{7}$ Reference group for type of social network is Member of Mahila Mandal. 